\title{
Time for a Real Shift to Relations: Appraisal of Social Network Analysis Applications in the UK Construction Industry
}

\author{
Ximing Ruan, (University of the West of England, UK) \\ Edward Ochieng, (Liverpool John Moores University, UK) \\ Andrew Price, (Loughborough University, UK) \\ Charles Egbu, (University of Salford, UK)
}

\begin{abstract}
The Social Network Analysis (SNA) has been adopted in the UK construction management research and generated meaningful insights in analysing project management organisations from network perspectives. As an effective tool, social network analysis has been used to analyse information and knowledge flows between construction project teams which are considered as the foundation for collaborative working and subsequently improving overall performance. Social network analysis is based on an assumption of the importance of relationships among interacting units. The social network perspective encompasses theories, models and applications that are expressed in terms of relational concepts or processes. Many believe, moreover, that the success or failure of organisations often depends on the patterning of their internal structure. This paper reviewes existing literatures on SNA applications in construction industry from three leading construction management journals. From the review, the research proposed some advance in the application of SNA in the construction industry.
\end{abstract}

Keywords: Social network analysis, Project organisations, Integration, Knowledge integration, Construction industry

\section{Introduction}

Social network analysis has been adopted as an analytical tool in the research into construction industry to provide indications of knowledge integration collaborative working and effective communication (Loosemore 1998; Chinowsky et al., 2008; El-Sheikha and Pryke 2010; Larsen 2011). Though it is generally agreed that this tool is effective in analysing project performance, there are some challenges in applying it in consideration of the special characters of construction industry. Social network analysis provides a method to understand informal networks within and between organisations and manage the informal networks systematically (Cross and Prusak, 2002). Social capital makes an organisation, or any collaborative group, more than a collection of individuals' intent on achieving their own private purposes. Social capital bridges the space between people, its characteristic elements and indicators include high levels of trust, robust personal networks and vibrant communities, shared understandings, and a sense of equitable participation in joint enterprise - all things that draw individuals together into a group. This kind of connection supports collaboration, commitment, ready access to knowledge and talent, and coherent organisational behaviour (Cohen et al. 2001).

The key difference that distinguishes social network analysis from other analysis and management methods is that social network analysis draws attention to informal networks in working places. Basically, social network analysis is used to measure and visualise relationships and flows between people, groups, organisations, computers or other information/knowledge processing entities, which complies with Drucker's assertion that 'it is this informal organization, rather than management, which actually determines rates of 
output, standards, job classification and job content.'(p174). McCarty et al. (2001) explain that Social Network Analysis (SNA) is both a theoretical perspective and a set of methods. In terms of theory, SNA extends and complements traditional social science by focusing on the causes and consequences of relations between people and among sets of people rather than on the features of individuals. In terms of method, SNA focuses on the measurement of relationships between people. In use of relational concepts, the following are important:

- Actors and their actions are viewed as interdependent (rather than independent) autonomous units. Relational ties (linkages) between actors are channels for transfer or "flow" of resources (either material or nonmaterial);

- Network models focusing on individuals views of the network structural environment as providing opportunities for or constraints on individual action;

- Network models conceptualise structure (social, economic, political, and so forth) as lasting patterns of relations among actors (Wasserman and Faust, 1994).

This paper evaluates the current application of social network analysis in construction context. Some suggestions and recommendations are made at the end in attempt to advance the application of social network analysis in construction industry. The next section introduces some key concepts in adopting network perspective in research in construction industry. The third section evaluates the key contributions from existing literature in social network analysis in the UK construction industry. Discussions and final recommendations are presented at the end.

\section{Network Perspective}

Traditionally the research into the UK construction industry focused on how to improve the competitive advantages of individual organisations. Not surprisingly these researches paid close attention to the attributes of individual organisations. The individual organisations are analysed from a range of facets including overall strategy, human resource management in turbulent project processes, leadership and team working etc. Following two government reports in 1994 and 1998 calling for changes, the UK construction industry has been attempting to improve its overall performance by introducing some managerial concepts from manufacturing industry (Latham 1994; Egan 1998). These management frameworks include Supply Chain management in construction and later Lean Construction, Partnering, Quasifirm, and Knowledge Management. In order to achieve the benefits from the different management approaches, all the participants in the construction project process are expected to display cooperative and collaborative working patterns based on trust and mutual support. Following the introduction of the above management approaches, the research in construction industry started shifting from individual organisational attributes towards network perspective, which means the research and analysis into construction organisations shift from pure economic dimension towards research taking into account of social dimension. The organisational behaviours in construction project process are analysed in their social context rather than economic motivations.

Though the management approaches listed above take into account the social dimension, their main emphases are still on business transactions in order to maximum the economic benefits. Tichy et al. (1979) advocates the network perspective in the study of organisational behavior and emphasises the social dimension rather than business benefits. According to Seufert et al. (1999), the term 'network' designates a social relationship between actors. Actors in a social network can be persons, groups, but also collectives of organisations, communities or even societies. The relationships evolving between actors can be categorised according to content (e.g., products or services, information, emotions), form (e.g., duration and closeness of the relationship) and intensity (e.g., communicationfrequency). Since the boundaries of networks are difficult to determine, blurred boundaries are constructed socially by the network members. Grandori and Soda (1995) considered

Ruan, X et al. (2013) 'Time for a real shift to relations: appraisal of Social Network Analysis applications in the UK construction industry', Australasian Journal of Construction Economics and Building, 13 (1) 92-105 
networks as nexuses of integration mechanisms encompassing all the range of organisational inter-firms coordination and cooperation. Network perspectives build on the general notion that economic actions are influenced by the social context in which they are embedded and that actions can be influenced by the position of actors in social networks (Gulati, 1998).

Similarly, Powell (1990) asserted that a network is a form of organisation in business practice. Network relations are perceived as the most central feature in moving the industry forward in the perspective of the "network form" (Powell, 1990). The functional explanation for the emergence of the "network form" claims that the opportunities for innovation exist within firms as well as in their external networks, and the ability of an organisation to learn results from its capacity to utilise both its own internal capabilities and the opportunities within its network through various forms of collaboration. In the context of networking, "network forms" of organisation have been described as a source of value for the firm (Kogut, 2000). Network based industries can be expected to generate new forms of collaboration, in which network partnerships will be based on maximising resource utilisation subject to the equitable distribution of returns, rather than on individual firms maximising their profits (Miles, et al., 1998). Some authors (Thorelli, 1986; Siebert, 1991; Sydow 1992) viewed networks as a hybrid form of organisation since networks have features of market and hierarchy. This form of organisation demonstrates stronger incentives and adaptive capabilities than hierarchies, but can offer more administrative control than markets (Williamson, 1994).

Due to the division of labour and accompanying fragmentation, specialisation and distribution of knowledge, it becomes a requisite to integrate and thus share the diversity of complementary knowledge in order to produce complex products and services, this feature is enhanced in the construction industry. An organisational setting is implemented or emerges because none of the actors involved can produce the collective outcome individually (Boer et al, 2002). Therefore, Reich (1991: p.81) regards a firm as a facade, behind which an array of decentralised groups and subgroups exist continuously contracting with similar diffuse working units all over the world. This perspective reinforces the significance of the relationships between organisations in order to manage business successfully, and calls for a network perspective to improve business management performance.

Similarly, Nohria and Eccles (1992) advocate a network perspective on organisational management for five important reasons:

- All organisations are social networks and therefore need to be addressed and analysed in terms of a set of nodes linked by social relationships;

- The environment in which an organisation operates might be viewed as a network of other organisations;

- Organisations are suspended in multiple, complex, overlapping webs of relationships and we are unlikely to see the overall pattern from the point of view of one organisation;

- Actions (attitudes and behaviour) of actors in organisations can best be explained in terms of their position within networks of relationships;

- The comparative analysis of organisations must take into account their network characteristics.

By taking the network perspective, managerial concerns shift from the consideration and protection of the boundaries of a firm to the management of and care for relationships (Seufert et al. 1999). In the empirical study of strategic alliances, Gulati (2000) points out that network facilitate firms in the network in gathering superior information, thus reducing

Ruan, X et al. (2013) 'Time for a real shift to relations: appraisal of Social Network Analysis applications in the UK construction industry', Australasian Journal of Construction Economics and Building, 13 (1) 92-105 
the informational asymmetries which otherwise may cause higher transaction cost. Furthermore, networks can mitigate transaction costs by making opportunism more costly because of reputational effects. Businesses take time to build reputations in society, but this reputation can be damaged overnight. Consequently, it is essential that firms exercise caution in protecting their reputation, and the network can help create a strong disincentive against opportunistic behaviour (Wang et al. 2004). Wang et al. (2004) viewed inter-firm networks as recourses which enable business to sustain above-average performance because they meet three criteria established by Barney (1991): resources being valuable, resources being rare and resources being imperfectly imitable. While the ties between the participating organisations become less important in traditional analysis approaches, as illustrated in Figure 1, the ties become imperative and a dominating issue in evaluating business performance in a network approach, which is illustrated in Figure 2.

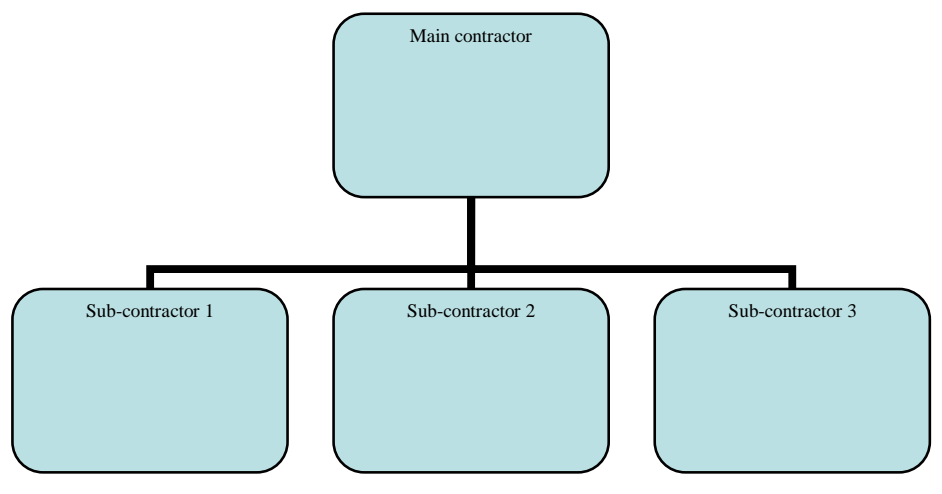

Figure 1 Traditional analysis of business management

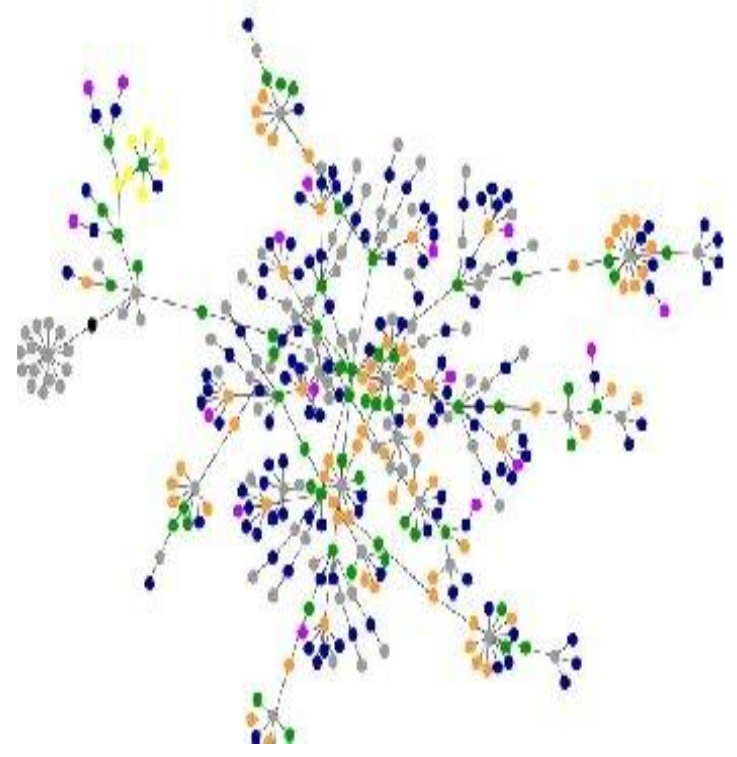

Figure 2 Boundaries between organisations

In Figure 2, all the boundaries between the organisations become less important and the network is considered as an overarching organisation within which the individual organisations function and pursue diversified goals. Network organisations are characterised by five key organisational principles:

- Unifying purpose: common views, values, and goals hold a network together. A shared focus on desired results sustains synchronised operations and network directionality;

Ruan, X et al. (2013) 'Time for a real shift to relations: appraisal of Social Network Analysis applications in the UK construction industry', Australasian Journal of Construction Economics and Building, 13 (1) 92-105 
- Independent members: each member of the network, whether an individual, company, or country, can continue to sustain its independent existence while benefiting from being part of the whole;

- Voluntary links: the distinguishing feature of networks is their links, as partners join forces voluntary;

- Multiple leaders: fewer bosses, more leaders. Each person or group in a network has something unique to contribute at some point of the process. With more than one leader, the network as a whole has greater resilience;

- Integrated levels: networks are multilevel, not flat. Networks operate on different levels, i.e. co-operation between organisations, departments and people (Lipnack and Stamps, 1994).

Though the five principles are useful for identifying networked organisations, they fail to explain how to create a successful networked organisation, as most of the features concluded above are developed without formal organisational management intervention. At organisational strategic level, inter-firm relationships have increasingly become a core component. They constitute valuable capital because they provide access to capabilities and resources that may otherwise be unavailable (Koka and Prescott, 2002). In regard to organisations in project management practices, Jones (1999) noted that the project organisation is best thought of as a project network, because projects are normally produced through a dynamic network of transactions involving specialised firms, subcontractors and freelancers. But this perspective has not been widely accepted by practitioners in the construction industry who constantly display adversarial relationships and work more competitively than collaboratively. The social network analysis perspective, along with its analytical tools, has been introduced into construction project management discipline which shadows a different light to understand the interactions between organisations in project processes.

\section{Method}

It is becoming difficult to ignore the social interactions and their impacts on analysing project teams. Firms have to take into account the reactions of relevant project participants and stakeholders in formulating their project plans and decisions. Not surprisingly, Social Network Analysis, which provides an effective tool to analyse the social interactions, has attracted considerable attention in analysing project team practices, revealing hidden working ties which are not visible from formal organisational chart. So far most of the attention on project teams has been drown on the formal organisational institutions. This section starts with the data collection process which presents the research results from three leading construction management journals in order to examine the current application of social network analysis in construction industry. The results show that the application of Social Network Analysis in construction industry is still limited, and the application of social network analysis and theories from network perspective in construction industry needs to be advanced.

\section{Basic Concepts}

The social network model was created based on criticisms of neo-classical economics models proposed by Williamson (1994), in which transaction activities are directed by bounded rationality and opportunism (Gordon and McCann 2000). The 'social-network model' proposes that there is more order to inter-firm interactions and less order to intra-firm interactions than the economic models would imply (Granovetter, 1985). Social networks of certain strong interpersonal relationships can be stronger than firm boundaries, with the result that many inter-firm social interactions may be stronger than their intra-firm counterparts (Gordon and McCann 2000). People use their social network as important resources for information and knowledge to accomplish their job. Freeman (2005) suggests

Ruan, X et al. (2013) 'Time for a real shift to relations: appraisal of Social Network Analysis applications in the UK construction industry', Australasian Journal of Construction Economics and Building, 13 (1) 92-105 
that social network analysis focus on two structural patterns of the ties that link social actors. The patterns can reveal subsets of actors that are organised into cohesive social groups and divulge subsets of actors that occupy equivalent social positions or roles. Therefore, the actor-by-actor ties provide basic data for social network analysis.

The broad majority of social network studies use either "whole-network" or "egocentric" designs. Whole-network studies examine sets of interrelated objects or actors that are regarded for analytical purposes as bounded social collectives, although in practice network boundaries are often permeable and/or ambiguous. For example, supportive connections in a group of researchers, helping activities in a classroom of people, by measuring relationships between all units, the analysis reveals the properties of relationships in the whole network. The boundary of "whole-network" analysis is pre-set by researchers. The second one is the "ego-centric" approach. Starting from a specific unit for research, this method collection relational connections with other "alters" (chosen according to the research aims), which later determine the final boundary of the whole network. It is a method to study how relational influences produce efforts on the individual.

\section{Data Collection}

Research papers were searched from three leading construction journals, namely Construction Management and Economics, Journal of Construction Engineering and Management, and Engineering, Construction and Architectural Management. The first two are ranked as two star journals and the last one as a one star journal. The set duration for this search is from 10/2002-10/2012, and 'Social Network' was used in searching titles, abstracts and key words from the three journals.

\section{Data Analysis}

Two-hundred and seventy-seven papers were found from Construction Management and Economics, however, further reading shows that most papers merely used 'social' and 'network' separately without any discussion or application of Social Network Analysis. For instance, some papers used social housing or business networking were included in the research results. Eventually only fourteen papers from Construction Management and Economics are selected for this study. Journal of Construction Engineering and Management, and Engineering, Construction and Architectural Management have four papers respectively which met the criteria of this study, which result in only twenty-two papers from these three leading construction management journals for further study.

\section{- Engineering, Construction and Architectural Management (ECAM)}

Strictly speaking, none of the four papers from our refined search in ECAM used Social Network Analysis. However, they all approached project management problems by a network perspective, which pays close attention to relationships between participants in light of the project performance and related problems. Only the first two papers were taken into account in our review as the third paper is a literature review on contractor-supplier relationships, and the fourth paper focused how business networks contribute to organisational business development rather than relating network theory to project process. Table 1 summarises the two papers used network approach to investigate project process. Although the approach used in the paper by Sandhu and Helo (2006) is similar to social network analysis, no SNA literature was referenced and the ties are dependencies between actors, resources and activities. 


\begin{tabular}{|l|l|l|l|l|}
\hline \multicolumn{1}{|c|}{ Paper } & \multicolumn{1}{|c|}{ Research focus } & $\begin{array}{c}\text { Whether } \\
\text { SNA was } \\
\text { applied }\end{array}$ & $\begin{array}{c}\text { What } \\
\text { measurements } \\
\text { were used }\end{array}$ & $\begin{array}{c}\text { How the network } \\
\text { was } \\
\text { established/defined }\end{array}$ \\
\hline $\begin{array}{l}\text { Sandhu, M and Helo,P. } \\
\text { (2006) A network approach } \\
\text { to project business analysis }\end{array}$ & $\begin{array}{l}\text { To describe and analyse } \\
\text { project businesses from a } \\
\text { network approach, } \\
\text { present a network-based } \\
\text { framework on } \\
\text { understanding key factors } \\
\text { contributing to project } \\
\text { success }\end{array}$ & No & N/A & $\begin{array}{l}\text { Working relationships } \\
\text { and inter- } \\
\text { dependencies } \\
\text { between participants } \\
\text { in project process }\end{array}$ \\
\hline $\begin{array}{l}\text { Davis, P.R. and Walker, } \\
\text { D.H.T. (2009) Building } \\
\text { capability in construction } \\
\text { projects: a relationship- } \\
\text { based approach }\end{array}$ & $\begin{array}{l}\text { How relationship-based } \\
\text { approach and social } \\
\text { capital can contribute to } \\
\text { improvement of project } \\
\text { performance }\end{array}$ & No & N/A & Working relationship \\
\hline
\end{tabular}

\section{- Journal of Construction Engineering and Management}

All the four papers from our refined search adopted Social Network Analysis in their studies which are summarised below in Table 2:

\begin{tabular}{|c|c|c|c|c|}
\hline Paper & Research focus & $\begin{array}{l}\text { Whether } \\
\text { SNA was } \\
\text { applied }\end{array}$ & $\begin{array}{c}\text { What } \\
\text { measurements } \\
\text { were used }\end{array}$ & $\begin{array}{c}\text { How the network } \\
\text { was } \\
\text { established/defined }\end{array}$ \\
\hline $\begin{array}{l}\text { Paul Chinowsky; James } \\
\text { Diekmann; and Victor } \\
\text { Galotti (2008) Social } \\
\text { network model of } \\
\text { construction }\end{array}$ & $\begin{array}{l}\text { The focus on project } \\
\text { outcome should shift focus } \\
\text { of construction project } \\
\text { management from } \\
\text { efficiency of projects to } \\
\text { high performance project } \\
\text { teams. The social network } \\
\text { model adopts a network } \\
\text { perspective in managing } \\
\text { project team performance } \\
\text { with special focus on } \\
\text { knowledge and information } \\
\text { sharing }\end{array}$ & Yes & $\begin{array}{l}\text { Network Density } \\
\text { and actor } \\
\text { distance }\end{array}$ & $\begin{array}{l}\text { Communication } \\
\text { between Project team } \\
\text { members }\end{array}$ \\
\hline $\begin{array}{l}\text { Paul S. Chinowsky1; James } \\
\text { Diekmann; and John } \\
\text { O'Brien (2010) Project } \\
\text { Organisations as social } \\
\text { networks }\end{array}$ & $\begin{array}{l}\text { How to improve team } \\
\text { effectiveness by building } \\
\text { up inter-organisational } \\
\text { knowledge exchange } \\
\text { network }\end{array}$ & Yes & Network Density & $\begin{array}{l}\text { Knowledge exchange } \\
\text { activities in project } \\
\text { process }\end{array}$ \\
\hline $\begin{array}{l}\text { Heedae Park; Seung H. } \\
\text { Han, M.ASCE; Eddy M. } \\
\text { Rojas; JeongWook Son; } \\
\text { and Wooyong Jung (2011). } \\
\text { Social network analysis of } \\
\text { collaborative ventures for } \\
\text { overseas construction } \\
\text { projects }\end{array}$ & $\begin{array}{l}\text { Inter-firm collaboration } \\
\text { networks and their effect } \\
\text { on organizational } \\
\text { performance in the } \\
\text { construction industry, }\end{array}$ & Yes & $\begin{array}{l}\text { Density, } \\
\text { directional ties, } \\
\text { betweeness } \\
\text { centrality, } \\
\text { closeness } \\
\text { centrality }\end{array}$ & $\begin{array}{l}\text { Collaborative working } \\
\text { relationships between } \\
\text { firms }\end{array}$ \\
\hline $\begin{array}{l}\text { Brad W. Wambeke, } \\
\text { M.ASCE; Min Liu, } \\
\text { A.M.ASCE; and Simon M. } \\
\text { Hsiang (2012) Using pajek } \\
\text { and centrality analysis to } \\
\text { identify a social network of } \\
\text { construction trades }\end{array}$ & $\begin{array}{l}\text { To identify key } \\
\text { subcontractors in a project } \\
\text { process by social network } \\
\text { analysis }\end{array}$ & Yes & $\begin{array}{l}\text { Degree } \\
\text { centrality and } \\
\text { Eigenvector } \\
\text { Centrality }\end{array}$ & $\begin{array}{l}\text { Task dependency } \\
\text { between project main } \\
\text { contractor and } \\
\text { subcontractors }\end{array}$ \\
\hline
\end{tabular}

Although the four papers used social network analysis, it is difficult to ignore the fact that all the four papers were published from 2008-2012.

Ruan, X et al. (2013) 'Time for a real shift to relations: appraisal of Social Network Analysis applications in the UK construction industry', Australasian Journal of Construction Economics and Building, 13 (1) 92-105 


\section{- Construction Management and Economics(CME)}

There are fourteen papers from Construction Management Economics applied social network analysis in their studies into construction project management, which are summarised in Table 3.

\begin{tabular}{|c|c|c|c|c|}
\hline Paper & Research focus & $\begin{array}{l}\text { Whether } \\
\text { SNA was } \\
\text { applied }\end{array}$ & $\begin{array}{c}\text { What } \\
\text { measurements } \\
\text { were used }\end{array}$ & $\begin{array}{c}\text { How the network } \\
\text { was } \\
\text { established/defined }\end{array}$ \\
\hline $\begin{array}{l}\text { Stephen D. Pryke (2004) } \\
\text { Analysing construction } \\
\text { project coalitions: exploring } \\
\text { the application of social } \\
\text { network analysis }\end{array}$ & $\begin{array}{l}\text { How network approach } \\
\text { can assist in } \\
\text { understanding coalitions in } \\
\text { construction projects? }\end{array}$ & Yes & Centrality & Information exchange \\
\hline $\begin{array}{l}\text { Alexander Styhre, Per Erik } \\
\text { Josephson and Ingeborg } \\
\text { Knauseder (2004) } \\
\text { Learning capabilities in } \\
\text { organisational networks: } \\
\text { case studies of six } \\
\text { construction projects }\end{array}$ & $\begin{array}{l}\text { How organisational } \\
\text { learning capacities are } \\
\text { developed during } \\
\text { construction project } \\
\text { management process from } \\
\text { a network perspective }\end{array}$ & No & & $\begin{array}{l}\text { Knowledge sharing } \\
\text { between project } \\
\text { participants at } \\
\text { organisational level }\end{array}$ \\
\hline $\begin{array}{l}\text { Stephen D. Pryke (2005) } \\
\text { Towards a social network } \\
\text { theory of project governance }\end{array}$ & $\begin{array}{l}\text { To understand project } \\
\text { governance from a social } \\
\text { network analysis approach } \\
\text { by measuring network } \\
\text { density and actor centrality }\end{array}$ & Yes & $\begin{array}{l}\text { network density } \\
\text { and actor point } \\
\text { centrality }\end{array}$ & $\begin{array}{l}\text { Contractual, } \\
\text { performance } \\
\text { incentive and } \\
\text { information exchange }\end{array}$ \\
\hline $\begin{array}{l}\text { Alexander Styhre (2008) } \\
\text { The role of social capital in } \\
\text { knowledge sharing: the case } \\
\text { of a specialist rock } \\
\text { construction company }\end{array}$ & $\begin{array}{l}\text { To examine the } \\
\text { knowledge acquisition } \\
\text { patterns within a } \\
\text { connected network }\end{array}$ & No & $\mathrm{N} / \mathrm{A}$ & $\begin{array}{l}\text { Knowledge sharing } \\
\text { activities }\end{array}$ \\
\hline $\begin{array}{l}\text { Catherine Comet (2009) } \\
\text { Social capital and profits of } \\
\text { small firms in the French } \\
\text { construction industry }\end{array}$ & $\begin{array}{l}\text { How can social capital and } \\
\text { social networks improve } \\
\text { companies' performance } \\
\text { in construction industry }\end{array}$ & No & $\mathrm{N} / \mathrm{A}$ & $\begin{array}{l}\text { Collaboration } \\
\text { between project } \\
\text { participants }\end{array}$ \\
\hline $\begin{array}{l}\text { Alexander Styhre and } \\
\text { Pernilla Gluch (2010) } \\
\text { Managing knowledge in } \\
\text { platforms: boundary objects } \\
\text { and stocks and flows of } \\
\text { knowledge }\end{array}$ & $\begin{array}{l}\text { How knowledge is stored } \\
\text { and shared between } \\
\text { project participants }\end{array}$ & No & & $\begin{array}{l}\text { Knowledge } \\
\text { integration and } \\
\text { sharing between } \\
\text { project participants }\end{array}$ \\
\hline $\begin{array}{l}\text { Ahmed El Sheikh and } \\
\text { Stephen D. Pryke (2010) } \\
\text { Network gaps and project } \\
\text { success }\end{array}$ & $\begin{array}{l}\text { to examine project inter } \\
\text { and intra networks for } \\
\text { effective project } \\
\text { governance with combined } \\
\text { use of gap analysis and } \\
\text { SNA }\end{array}$ & Yes & $\begin{array}{c}\text { Degree } \\
\text { Centrality and } \\
\text { Network density }\end{array}$ & \\
\hline $\begin{array}{l}\text { Abu Naser Chowdhury, Po- } \\
\text { Han Chen and Robert L.K. } \\
\text { Tiong (2011) Analysing the } \\
\text { structure of public-private } \\
\text { partnership projects using } \\
\text { network theory }\end{array}$ & $\begin{array}{l}\text { How to identify the } \\
\text { important players in PPP } \\
\text { projects with network } \\
\text { theory }\end{array}$ & Yes & $\begin{array}{l}\text { Betweenness } \\
\text { Centrality, } \\
\text { Closeness } \\
\text { centrality }\end{array}$ & $\begin{array}{l}\text { Contractual } \\
\text { relationships }\end{array}$ \\
\hline $\begin{array}{l}\text { Graeme D. Larsen (2011) } \\
\text { Understanding the early } \\
\text { stages of the innovation } \\
\text { diffusion process: } \\
\text { awareness, influence and } \\
\text { communication networks }\end{array}$ & $\begin{array}{l}\text { To investigate how actors } \\
\text { in an innovation diffusion } \\
\text { network become aware of } \\
\text { an innovation and then } \\
\text { how their opinion is } \\
\text { influenced }\end{array}$ & Yes & $\begin{array}{l}\text { Density of the } \\
\text { whole network }\end{array}$ & $\begin{array}{l}\text { Diffusion channel of } \\
\text { innovation in } \\
\text { construction projects }\end{array}$ \\
\hline
\end{tabular}

Ruan, X et al. (2013) 'Time for a real shift to relations: appraisal of Social Network Analysis applications in the UK construction industry', Australasian Journal of Construction Economics and Building, 13 (1) 92-105 


\begin{tabular}{|c|c|c|c|c|}
\hline Paper & Research focus & $\begin{array}{l}\text { Whether } \\
\text { SNA was } \\
\text { applied }\end{array}$ & $\begin{array}{c}\text { What } \\
\text { measurements } \\
\text { were used }\end{array}$ & $\begin{array}{c}\text { How the network } \\
\text { was } \\
\text { established/defined }\end{array}$ \\
\hline $\begin{array}{l}\text { Ximing Ruan , Edward G. } \\
\text { Ochieng , Andrew D.F. Price } \\
\text { and Charles O. Egbu (2012) } \\
\text { Knowledge integration } \\
\text { process in construction } \\
\text { projects: a social network } \\
\text { analysis approach to } \\
\text { compare competitive and } \\
\text { collaborative working }\end{array}$ & $\begin{array}{l}\text { How knowledge is } \\
\text { integrated between project } \\
\text { participants according to } \\
\text { their social network } \\
\text { patterns }\end{array}$ & Yes & $\begin{array}{l}\text { Betweenness } \\
\text { Centrality, } \\
\text { Closeness } \\
\text { centrality, } \\
\text { Network Density }\end{array}$ & $\begin{array}{l}\text { Knowledge } \\
\text { contribution towards } \\
\text { variation order } \\
\text { requirements }\end{array}$ \\
\hline $\begin{array}{l}\text { Rayyan Alsamadani , } \\
\text { Matthew Hallowell and Amy } \\
\text { Nicole Javernick-Will (2012) } \\
\text { Measuring and modelling } \\
\text { safety communication in } \\
\text { small work crews in the US } \\
\text { using social network } \\
\text { analysis }\end{array}$ & $\begin{array}{l}\text { To investigate the } \\
\text { frequency and structure of } \\
\text { effective safety } \\
\text { communication } \\
\text { within small project } \\
\text { teams }\end{array}$ & Yes & $\begin{array}{c}\text { Degree } \\
\text { centrality, } \\
\text { Network density, } \\
\text { and } \\
\text { betweenness } \\
\text { centrality }\end{array}$ & $\begin{array}{l}\text { Communication } \\
\text { between participants }\end{array}$ \\
\hline
\end{tabular}

\section{Discussions on SNA Applications in the UK Construction Industry}

From the tables which summarised the research papers adopted social network analysis, it is clear that the application of social network analysis is relatively new in the UK construction industry (El-Sheikha and Pryke, 2010), and the research from a social network analysis approach has favored whole-network method by which the relationships are measured by cohesion, density and distances. From the twenty-two papers selected for this study, it is evident that most of the ties and connections in these social networks were established by information/knowledge exchange or by task/contractual relationships in workplace during project processes. Although the literature sections of these papers placed great emphasis on social settings and project context in the study of issues relating to project performance, the 'social' interactions outside of the project processes and working place were not investigated. Social context should take into account social interactions which take place in social events in which social capital accumulate. Also the measurements adopted by these papers are limited to degrees, centralities and densities. The density is used as a measurement to reflect overall network collaboration or cohesion and centralities are used as a measurement to reflect relational patterns among those papers. However, the real meaning of such social constructs can be argued in practice (Larsen, 2011).

During the past ten years, only twenty papers were published in the three leading construction management journals used social network analysis as a tool to analyse different aspects of project performance. All of these papers used social network analysis established the ties between actors by a kind of relationships, namely contractual/intensive connections, communication and information channels, and knowledge contribution activities. Among these papers, several authors made significant contributions towards the application of SNA in construction project management. Pryke has studied a range of issues using SNA, including project governance (Pryke, 2005), project success factors (El-Sheikh and Pryke, 2010), and project coalitions (Pryke, 2004). Other papers used similar approaches to map the project management process from a social network analysis perspective and analysed different aspects by the established networks. The following discussion focuses on Pryke's papers but the arguments can be extended to other papers.

Pryke (2004) considers degree centrality as an effective means to measure power and influence of an organisation. The degree centrality can be understood as in a given network, an organisation has higher degree centrality if it has more ties than other organisations. Pryke (2004) suggested that a multi-layer of interdependent networks within project coalitions should be explored as the following:

Ruan, X et al. (2013) 'Time for a real shift to relations: appraisal of Social Network Analysis applications in the UK construction industry', Australasian Journal of Construction Economics and Building, 13 (1) 92-105 
- Networks of contractual relationships;

- Networks of performance incentives;

- Networks of information exchange, sub classified into:

Client requirements;

$>$ Design activities;

$>$ Progress management; and

Financial management (p.795, Pryke, 2004).

However, Pryke ignored the fact that the effective application of social network relies on social interactions based on informal relationships. For example, social network can analyse how some people can become powerful with their social ties, even if they do not have any formal authority that can be found from an organisational chart. These kinds of informal relationships, which social network analysis investigates, do not follow the formal relationship channels such as organisational charts and business contracts. Networks contractual relationship and performance incentives should be applied to determine the whole network boundaries rather than to establish the ties between firms as those relationships can be defined by traditional analytical methods. The critique of Pryke's paper can also be applied to other papers which did not take into account the informal social interactions outside of working places, as some papers adopted SNA measurements without strong justifications. Similarly, in Chinowsky's study (2010), it is not clear why the density is used as a single measurement to benchmark the team performance, and why the effectiveness of the ties between dyads are not considered.

In a recent research into project success in the UK construction industry, El-Sheikha and Pryke (2010) adopted social network analysis to map the communication pattern which has significant impact on client satisfaction and subsequently project success. El-Sheikha and Pryke (2010) consider that the application of social network analysis can be used to analyse the systems associated with delivering project through:

- Addressing problems at early stages and thus minimising any client surprises;

- Identifying and improving information exchange networks (Pryke, 2004) and reducing any possible discontinuity in financial incentives; and

- Achieving a balance between social and scientific aspects in management of projects.

However, social network is analytical in nature and can indicate the social network pattern and attributes under investigation, but it can be asked how this analytical tool can be used to 'improve information exchange networks' and 'reducing discontinuity in financial incentives' as social network analysis by itself does not provide any control methods. El-Sheikha and Pryke (2010) constructed information exchange networks between a range of project actors comprising of architect, construction project manager, employer's agent, quantity surveyor, contractor, service engineer and structural engineer. Not only are the networks differentiated by their foci on project time, cost and scope, but also the informal and formal discussions are distinguished to construct two networks. Nevertheless, it is not clearly explained in their paper what kind of discussion should be considered 'informal' if the discussions are about project delivery which is directly associated with contractual relationships and responsibilities. Meanwhile, the density of communication in this review is considered as a major means to evaluate the relationships between different actors, without acknowledging that communication frequency is not always directly linked with support and close relationships. Some actors in a network can communicate less than others due to closer relationships and shared understanding.

It is also worth mentioning that among all these papers, Chowdhury et al's study (2011) is the only one which adopted two-mode Social Network Analysis approach to establish the

Ruan, X et al. (2013) 'Time for a real shift to relations: appraisal of Social Network Analysis applications in the UK construction industry', Australasian Journal of Construction Economics and Building, 13 (1) 92-105 
network under investigation. This two-mode approach establishes the ties between members by mutual participations on particular events, rather than direct ties such as communication between members. Basically the two-mode social network analysis has two sets of actors and the ties between actors in one set are created by investigating their relationships to the other set. For example, a group of people can be considered as one set of actors and a range of social events can be considered as the other one. The ties between people are created by whether they are present at those events. The reason behind this approach is that 'individuals, by their agency, create social structures while, at the same time, social structures develop an institutionalized reality that constrains and shapes the behavior of the individuals embedded in them' (Hanneman and Riddle, 2005). Therefore, data like these involve two levels of analysis (or two "modes"). Normally, the term "affiliation" is used to describe which actors are affiliated (present, or members of) which macro structures. This approach can look into the social dimension and how individuals make meanings of the events or groups in a social context.

\section{The Way Forward}

The paper has reviewed relevant concepts in social network analysis and its application in the UK construction context. The UK construction industry has adopted a number of management methods and analytical tools from other disciplines and industries, such as Total Quality Management, Supply Chain Management. Not surprisingly, it takes some efforts to apply those methods in the construction context due to the special character of construction management. It is generally agreed that social network analysis provides a quantitative tool, which is positivism in nature, to analyse interactions between actors in project management process in construction industry; the actors can be either individual persons or organisations. The connections of the social network between all the participants are established by the participant themselves in the context of project process and there is no exploration of 'social' dimension in larger social context, where participants establish or reinforce their social ties in social interactions. It can be said that the analysis of social networks in construction industry merely measures relations at the micro level where the ties of individuals are examined, the macro structure, such as subgroups of special interests, cannot be revealed.

This reflects that the current applications of social network analysis are limited to one-mode social networks, where a set of actors are linked by predefined ties. From the studies reviewed, the ties can be information, discussion, supportive activities etc. The application of two-mode social network analysis has not been fully explored in construction industrial context with only one of the reviewed papers having adopted the two-mode approach.

Furthermore, social network analysis should be considered as a complementary tool to be used in combination with other research methods in order to reveal the real meaning of the data presented in social diagrams (Larsen, 2011). For instance, the density of a network is positively related to collaborative working, trust, and frequency of communications in these papers. However, this can be negatively related to these factors as tacit understanding between members can result in a network with less density if this network is measured by communication frequency. Although SNA is embedded in the positivist perspective (Larsen, 2011), the data collection process and interpretations are more interpretative in nature as the ties established by support, trust, collaborative working and effective communications are subjectively perceived and socially constructed. The reconciliation of the both positivism and interpretivism in social network analysis should be justified in future studies.

\section{Conclusion and Recommendations}

Though the social network analysis is considered as a relatively new approach in the construction industry, it meets the trend that the research foci in construction management is shifting from economic activities to include more social dimensions. However, this paper

Ruan, X et al. (2013) 'Time for a real shift to relations: appraisal of Social Network Analysis applications in the UK construction industry', Australasian Journal of Construction Economics and Building, 13 (1) 92-105 
reveals that the application of the social network analysis in construction industry needs further development in terms of research design and data interpretations to serve as a strong analytical tool. Moreover, the current application of social network analysis in the construction industry is limited by focusing only on ties established within workplace, the ties created or reinforced in social contexts remaining unexplored, and as a consequence the strengths of the social network analysis are not fully explored. Therefore, further research is needed to advance the application of social network analysis in construction industry by developing stronger justification for the selection of measurements, the adoption of twomode analysis and taking into account more of the social context to realise the full potential of social network analysis in the construction industry.

In summary, there is a need for:

- Strong justification of the adoption of social network analysis as an effective tool in order to interpret the real meaning of these connections in real life.

- The use of two-mode social network analysis which takes into account social events should be advanced further.

- Taking into account social interactions outside the work place in data collection in order to justify the use of SNA which places emphasis on social context.

- Use social network analysis as a complementary tool in combination with other tools in order to generate meaningful insight.

\section{References}

Alsamadani, R., Hallowell, M. and Javernick-Will, A.N. (2012) 'Measuring and modelling safety communication in small work crews in the US using social network analysis', Construction Management and Economics, 1-12

Barney, J. B. (1991) 'Firm resources and sustained competitive advantage', Journal of Management, 17 (1), 99-120

Boer, N. I., van Baalen, P. J., and Kumar, K. (2002) 'The implications of different models of social relations for understanding knowledge sharing', Paper presented at the 3rd European Conference on Organisational Knowledge, Learning, and Capabilities, ALBA, Athens, April, 3-4

Chinowsky, P. S. Diekmann, J., and Galotti, V. (2008) 'The Social Network Model of Construction', Journal of Construction Engineering and Management, 134 (10), 804-810

Chinowsky, P., Diekmann, J., and O'Brien, J. (2010) 'Project Organisations as social networks', Journal of Construction Engineering and Management, 136, 452-458

Chowdhury, A.N., Chen, P.H., Tiong R.L.K. (2011) 'Analysing the structure of public-private partnership projects using network theory', Construction Management and Economics, 29 (3), 247-260

Cohen, W.M., Malerba, F., Mowery, D. and Winter, S. (2001) 'Introduction to the special issue in honor of Richard Nelson', Journal of Industrial and Corporate Change, 10, 549-559

Comet, C. (2009) 'Social capital and profits of small firms in the French construction industry', Construction Management and Economics, 27 (4), 411-418

Cross, R., Parker, A., Prusak, L and Borgatti, S. (2001) 'Knowing what we know: Supporting knowledge creation and sharing in social networks', Organisational Dynamics 3 (2), 100-120, re-printed in Darden Learning Primer and Creating Value with Knowledge: Insights from the IBM Institute for Knowledge-Based Organisations

Cross, R. and Prusak, L. (2002) 'The people that make organisations stop - or go', Harvard Business Review, 80 (6), 104-112

Drucker, P. (1950) The New Society: The Anatomy of industrial order, New York: Harper and Brothers

Ruan, X et al. (2013) 'Time for a real shift to relations: appraisal of Social Network Analysis applications in the UK construction industry', Australasian Journal of Construction Economics and Building, 13 (1) 92-105 
Egan, J. (1998) Rethinking Construction. Department of the Environment, HMSO, UK El-Sheikha, A and Pryke, S. (2010) 'Network gaps and project success', Construction Management and Economics, 28 (12), 1205-1217

Freeman, L. C. (2005) 'Graphic techniques for exploring social network data' in Models and Methods in Social Network Analysis, eds, Carrington, P. J., Scott, J. and Wasserman, S., Cambridge University Press, NY

Grandori, A. and Soda, G. (1995) 'Inter-firm networks: Antecedents, mechanisms and forms', Organization studies, 16 (2), 183-216

Granovetter, M. (1985) 'Economic action and social structure: The problem of embeddedness', American Journal of Sociology, 91 (3), 481-510

Gordon, I. R. and Mccann, P. (2000) 'Industrial clusters: Complexes, agglomeration and/or social networks?', Urban Studies, 37 (3) 513-532

Gulati, R. (1998) 'Alliances and networks', Strategic Management Journal, 19 (4), 293-317

Gulati, R., Nohria, N. and Zaheer, A. (2000) 'Strategic Networks', Strategic Management Journal, 21 (3), 203-216

Hanneman, R. A. and Riddle, M. (2005) Introduction to social network methods, University of California, Riverside, CA

Jones, B. (1999) 'Bounded rationality', Annual Review of Political Sciences, 22, 297-321

Kogut, B. (2000) 'The network as knowledge: Generative rules and the emergence of structure', Strategic Management Journal, 21, 405-425

Koka, B. R. and Prescott, J. E. (2002) 'Strategic alliances as social capital: A multidimensional view', Strategic Management Journal, 23, 795-816.

Larsen, G. (2011) 'Understanding the early stages of the innovation diffusion process: awareness, influence and communication networks', Construction Management and Economics, 29 (10) 987-1002

Latham, M. (1994) Constructing the Team Department of the Environment, HMSO, UK

Lipnack, J. and Stamps, J. (1997) Virtual Teams: Reaching across Space, Time, and Organizations with Technology, J. Wiley, New York, Chichester

Loosemore, M. (1998) 'The influence of communication structure upon management efficiency', Construction Management and Economics, 16 (6), 661-671

McCarty, C., Killworth, P.D., Bernard, H. R., Johnsen, E. and Gene A. S. (2001) 'Comparing two methods for estimating network size', Human Organisation, 60, 28-39

Miles, G., Miles, R. E., Perrone, V. and Edvinsson, L. (1998) 'Some Conceptual and research barriers to the utilization of knowledge', California Management Review, 40 (3), 281-288

Nohria, N., Eccles, R. G. (1992) Networks and organisations: Structure, form, and action, Harvard Business School Press, Boston, Mass

Park, H., Han, S., Rojas, E., Son, J., and Jung, W. (2011) 'Social network analysis of collaborative ventures for overseas construction projects', Journal of Construction Engineering Management, 137 (5), 344-355

Pryke, S. D. (2004) 'Analysing construction project coalitions: Exploring the application of social network analysis', Construction Management and Economics, 22 (8), 787-797

Pryke, S.D. (2005) 'Towards a social network theory of project governance', Construction Management Economics, 23 (9) 927-39

Powell, W. W. (1990) 'Neither market nor hierarchy: Networks forms of organisation', Research in Organisational Behavior, 12, 295-336

Ruan, X et al. (2013) 'Time for a real shift to relations: appraisal of Social Network Analysis applications in the UK construction industry', Australasian Journal of Construction Economics and Building, 13 (1) 92-105 
Reich, R. B. (1991) The Work of Nations: Preparing Ourselves for 21st-Century Capitalism, A.A. Knopf 1991, New York

Seufert, A., Von Krogh, G. and Bach, A. (1999) 'Towards knowledge networking', Journal of Knowledge Management, 3 (3), 180-190

Siebert, H. (1991) 'Konomische analyse von unternehmungsnetzwerken' in Managementforschung, 1, eds, Staehle, W. H. and Sydow, J., DeGruyter, Berlin, New York, 291-311

Styhre, A., Josephson, P.E and Knauseder, I (2004) 'Learning capabilities in organizational networks: case studies of six construction projects', Construction Management and Economics, 22 (9), 957-966

Styhre, A. (2008) 'The role of social capital in knowledge sharing: the case of a specialist rock construction company', Construction Management and Economics, 26 (9), 941-951

Styhre, A and Gluch, P. (2010) 'Managing knowledge in platforms: boundary objects and stocks and flows of knowledge', Construction Management and Economics, 28 (6), 589-599

Sydow, J. (1992) Strategische netzwerke, Evolution und organisation, Gabler, Wiesbaden

Thorelli, H. B. (1986) 'Networks: Between markets and hierarchies', Sloan Management Review, 737-51

Tichy, N., Tushman, M. and Fombrun, C. (1979) 'Social networks analysis for organizations', Academy of Management Review, 4, 507-519

Wambeke, B., Liu, M., and Hsiang, S. (2012) 'Using pajek and centrality analysis to identify a social network of construction trades', Journal of Construction Engineering Management, 138 (10) 1192-1201

Wang, Y., Ahmed, P. K. and Worrall, L. (2004) 'Understanding inter-firm network: A theoretical review', International Journal of Management Concepts and Philosophy, 1 (1), 173-198

Wasserman, S. and Faust, K. (Eds.) (1994) Social Network Analysis: Methods and Applications, Cambridge University Press, Cambridge

Williamson, O. E. (1994) Comparative economic organisation: The analysis of discrete structural alternatives, Occasional Papers- International Center for Economic Growth, ALL

Ruan, X., Ochieng, E.G., Price, A.D.F and Egbu, C.O. (2012) 'Knowledge integration process in construction projects: a social network analysis approach to compare competitive and collaborative working', Construction Management and Economics, 30 (1), 5-19 